\title{
USAHA KECIL DAN MENENGAH KERIPIK TEMPE DI KECAMATAN BLIMBING KOTA MALANG UNTUK PENINGKATKAN PENDAPATAN USAHA
}

\author{
Fenny Suryanti, Kun Aussieanita Mediaswanti \\ Program Studi Teknik Kimia, Fakultas Teknik \\ Universitas Tribhuwana Tunggadewi Malang \\ e-mail : spabrina74@gmail.com
}

\begin{abstract}
ABSTRAK
Ipteks bagi masyarakat (IbM) merupakan salah satu bentuk pengabdian masyarakat yang memiliki keunggulan tersendiri. Tim pengusul kali ini mengambil lokasi pengabdian di daerah Malang pada UKM Kripik Tempe Elang Jawa dan UKM Kripik Tempe Selera Pemberani tepatnya di wilayah jalan Sanan Kelurahan Purwantoro Kecamatan Blimbing Kota Malang. Adapun tujuan tim pengusul IbM ini adalah ingin mengembangkan produksi kripik tempe sebagai ciri khas kota Malang yang bekerja sama dengan mitra untuk memperbaiki kualitas proses pembuatan dan pengemasan kripik tempe tersebut dengan harapan daya jangkau pemasaran mitra semakin luas, sehingga pendapatan mitra akan bertambah dan dapat meningkatkan taraf hidup keluarga.

Rencana kegiatan yang akan dilakukan pada mitra adalah dengan memberikan pelatihan dan pendampingan dalam membuat desain kemasan agar lebih menarik dalam pemasaran dan cara menganalisa untung rugi UKM dalam bentuk analisa BEP usaha serta pemberian alat pengiris tempe dan pengemas kripik tempe yang disesuaikan dengan kebutuhan mitra untuk mengembangkan usahanya sehingga produk yang dihasilkan akan lebih higienis saat pengirisan dan tahan lebih lama dalam penyimpanan dengan menggunakan kemasan plastik yang sesuai standar serta dapat dikemas lebih rapat dan rapi. Selain itu, tim pengusul juga memberikan triktrik dalam teknik komunikasi pemasaran agar kegiatan pemasaran yang selama ini kurang efektif, akan semakin berkembang dengan adanya model pemasaran baru yang ditawarkan oleh tim pengusul yakni pemasaran melalui media internet (website) dan personal selling serta cara mendesain kemasan yang lebih menarik bagi konsumen.
\end{abstract}

Kata kunci : Kripik tempe, Pemasaran, Alat pengiris, Alat pengemas.

\section{ABSTRACT}

Science and technology for society is one form of community service that has its own advantages. Proposer team this time taking the location service in the area of Malang on Elang Jawa of tempe chips UKM and UKM chips Tempe of Selera Pemberani in the way Courageous Village Purwantoro Sanan Blimbing district of Malang.

The purpose of the team proposer IbM of this is to develop the production of chips tempe as typical city of Malang are working with partners to improve the quality of the manufacturing process and packaging chips tempe with the hope of a range of partner marketing increasingly widespread, so that the partner revenue will grow and be able to improve family life.

Plan activities to be carried out on a partner is to provide training and assistance in making the packaging design to make it more attractive in marketing and how to analyze the costbenefit of UKM in the form of analysis BEP business as well as the provision of slicer tempeh and packaging chips tempe tailored to the needs of partners to expand its business so that the resulting product will be more hygienic when slicing and last longer in storage by using plastic packaging standards-compliant and can be packed more tightly and neatly. In addition, the team proposer also provide the tricks in the techniques of marketing communication that marketing 
activities which have been less effective, will grow with the new marketing model offered by the team proposing that marketing via the Internet (website) and personal selling as well as how to design packaging more appealing to consumers.

Keywords : Tempe crisps, Marketing, Tools slicer, packaging equipment.

\section{PENDAHULUAN}

\subsection{Analisis Situasi Untuk Pengusaha Mikro / Jasa Layanan}

\section{UKM Kripik Tempe "Elang Jawa" Sumber Daya Manusia}

Usaha kecil dan menengah pembuatan kripik tempe "Elang Jawa" berada di Jl. Sanan 129 A Blimbing Kota Malang, nomor telpon/HP 0341-9900404, akses jalan baik dan lancar dengan waktu tempuh kurang lebih 1 jam perjalanan serta bisa dikatakan sebagai industri rumah tangga (home made). Sebagai pimpinan usaha Bapak Ibrahim Nasrullah; bendahara Ibu Endang Sulistyoningsih, yang merupakan pasangan suami istri. Tenaga kerja yang ada pada usaha Kripik Tempe "Elang Jawa" berjumlah 3 orang yang berasal dari penduduk sekitar terdiri dari 1 orang di bagian iris, 1 orang $\mathrm{di}$ bagian bungkus/pengemasan, 1 orang di bagian goreng sedangkan untuk tenaga penjualan dilakukan sendiri oleh bapak Ibrahim. Dalam pembagian kerja tersebut kadangkadang masih serabutan. Alasan mendirikan usaha kripik tempe ini selain untuk menambah pendapatan keluarga juga mempunyai tujuan yaitu mengembangkan serta mempertahankan camilan khas malang yang berbahan dasar dari tempe.

\section{Kondisi Manajemen dan Investasi}

Manajemen usaha Kripik Tempe "Elang Jawa" yang dikelola sudah cukup baik, karena Bapak Ibrahim Nasrullah sebagai pemilik usaha juga berperan sebagai manajer. Kondisi manajemen sudah tertata dengan baik yang meliputi : pembagian kerja karyawan, pembukuan dan laporan keuangan usaha tetapi belum mampu membuat proyeksi keuangan untuk memastikan apakah pengembangan usaha akan menguntungkan atau sebaliknya. Bahan baku berupa tempe lokal yang di beli dari Malang Raya. Investasi meliputi : ruang tamu dengan ukuran $2 \times 2$ meter dan tempat proses berukuran $2 \times 1$ meter dan ruang tamu untuk pemasangan etalase jualan dan proses pengemasan serta dapur untuk proses penggorengan dan 1 (satu) buah kendaraan sepeda motor untuk pengangkut bahan dan pemasaran. Daerah pemasaran kurang luas meski terkadang sampai di luar kota diantaranya Bali dan Jakarta. Selain itu pemasaran yang sulit dikembangkan karena adanya persaingan dari munculnya usaha keripik tempe yang baru sehingga cenderung semakin merosot. Permintaan keripik tempe per minggu mencapai 300 bungkus tetapi hanya mampu mensuplai sekitar $40 \%$ dari permintaan atau sekitar 120 bungkus. Kebutuhan keripik tempe yang mendesak tidak bisa terpenuhi, kontinyuitas produksi tidak tercapai. Ada beberapa penawaran pinjaman dana kredit usaha dengan bunga rendah dari beberapa Bank tetapi mereka belum berani untuk mengambil kesempatan tersebut karena kurangnya pendapatan yang mereka miliki.

\section{Kondisi Produksi}

Pada aspek produksi usaha Keripik Tempe di "Elang Jawa" mempunyai kapasitas produksi relatif kecil yaitu 50-70 bungkus kripik tempe tiap minggunya yang 
sebelumnya bisa sampai mencapai 300 bungkus per goreng dengan berat bersih tiap bungkus kripik tempe adalah 200 gram atau 2 ons, sekaramg hanya mencapai $100-120$ bung-kus/minggu hal ini dikarenakan keterbatasan sarana yang digunakan yaitu saat proses pengemasan menggunakan lilin biasa untuk merekatkan kemasan dan tenaga kerja yang diperbantukan tidak banyak. Waktu yang dibutuhkan dalam proses produksi sekitar 18 jam. Kondisi ini menyebabkan Keripik Tempe "Elang Jawa" hanya mampu mensuplai kebutuhan konsumen sebesar $40 \%$ dari permintaan pasar 300 bungkus/minggu yaitu sekitar 120 bungkus/minggu.

Permasalahan yang dihadapi oleh usaha Keripik Tempe "Elang Jawa" adalah rendahnya produksi dikarenakan kurangnya tenaga kerja serta kurangnya sarana yang memadai dalam mengembangkan usaha ini. Semua dilakukan masih dengan cara-cara tradisional mulai dari proses pengirisan tempe sampai dengan pengemasan kripik tempe tersebut. Begitu pula dengan tingkat kehigienisan produk yang masih kurang karena kondisi dapur yang jadi satu dengan dapur rumah tangga dan tempat tinggal serta tanpa meng-gunakan alat untuk melindungi tangan pada saat pengemasan keripik tempe, sehingga bisa saja kuman dan lain-lain bisa terkontaminasi ke dalam keripik tempe tersebut serta pada saat pengirisan apabila pisau yang digunakan kurang bersih maka besar kemungkinan hasil produk kurang berkualitas sehingga tidak akan tahan lama dalam penyimpanan karena kurang higienis dalam pengolahan saat pengirisan tempe. Alat dan peralatan pada proses produksi mengolah bahan makanan yang digunakan haruslah higine dari unsur kimia termasuk karat dan kotoran (Anindia, 2003 )Untuk memperoleh tempe yang berkualitas baik, maka kedelai yang digunakan juga harus yang berkualitas baik dan tidak tercampur dengan biji-bijian yang lain, seperti jagung, kacang hijau dan biji-bijian lainnya. Selain itu, prosedur pengolahan harus dilakukan dengan cermat. Kebersihan tempat kerja dan kebersihan peralatan kerja akan meningkatkan kualitas tempe yang dihasilkan (Anonim, 2012). Selain itu tenaga kerja yang sangat minim menyebabkan produksi menjadi kurang maksimal, karena luas pemasaran yang masih kurang lebar sehingga pemesanan kripik menjadi terbatas pada area yang sama.

Kondisi dapur untuk proses penggorengan keripik tempe tersebut juga kurang memadai sehingga tidak dapat merasa nyaman dalam pengerjaannya, hal tersebut langsung dirasakan oleh pekerja di bagian penggorengan kalau hal tersebut cukup mengganggu dalam mengerjakan menggoreng keripik tempe karena dapur yang sempit serta ruangan yang panas. Begitupun dengan proses pengemasan yang masih sederhana dan konvensional, mengakibatkan waktu yang digunakan untuk mengemas keripik tersebut menjadi memakan waktu yang lama, sebab Keripik Tempe "Elang Jawa" milik Bpk. Ibrahim ini dalam mengemas keripik tempenya hanya menggunakan plastik ukuran standart dan ditutup dengan menggunakan api lilin.

Kemasan memegang peranan penting dalam sebuah industri, dengan kemasan menarik maka diharapkan omzet penjualan akan meningkat tajam. Bakat seni anda dituntut untuk dapat menampilkan kemasan yang baik hingga mata seseorang akan langsung terfokus pada produk anda dalam timbunan berbagai produk disekelilingnya. (Anonim, 2013)

Diperlukan tenaga kerja harus lebih dari satu orang jika menginginkan hasil produksi yang cepat. Daya simpan keripik juga hanya mampu memiliki kondisi baik sampai 2 minggu saja dan tidak boleh terkena sinar matahari, sehingga perlu adanya inovasi baru dalam bentuk jenis kemasan keripik tempe. Sebagai seorang 
pemilik usaha keripik tempe, pimpinan keripik tempe Elang Jawa berharap kehadiran komunitas pengusaha keripik tempe Sanan dapat memberikan dukungan kepada seluruh pengusaha kripik tempe yang ada di Sanan agar mereka tidak sampai gulung tikar.

\section{UKM Kripik Tempe "Selera Pemberani" Sumber Daya Manusia}

Usaha kecil dan menengah yang lain usaha pembuatan keripik tempe "Selera Pemberani" yang berada di Jl. Sanan Gg. 8A/242 Kelurahan Purwantoro Blimbing Kota Malang, no telpon 0341-498796, akses jalan baik dan lancar dengan waktu tempuh kurang lebih 1 jam perjalanan. Sebagai pimpinan usaha Ibu Ema Faiz Azizah, di mana usaha ini yang memulai adalah suami dari Ibu Ema yakni Bpk Arifin (Alm), kemudian diteruskan oleh Ibu Ema hingga saat ini. Tenaga kerja pembantu berjumlah 3 orang yang berasal dari penduduk sekitar terdiri dari bagian menggoreng kripik 2 orang, mengiris tempe 1 orang, pengemasan 1 orang yaitu Ibu Ema sendiri, serta pemasaran juga dilakukan sendiri oleh Ibu Ema. Pekerjaan yang mereka lakukan dilakukan secara bergiliran dengan tujuan supaya semua karyawan diharapkan bisa menguasai proses pembuatan keripik tempe jadi dilakukan secara serabutan yang nantinya jika salah satu dari mereka ingin membuka usaha sendiri dapat mengambil ilmu yang dulu mereka pernah kerjakan sehingga membuka kesempatan bagi pengusaha baru untuk bisa berkembang. Tujuan dari keluarga Ibu Ema mendirikan usaha keripik tempe "Selera Pemberani" ini adalah untuk mencari penghasilan utama keluarga. Tenaga kerja untuk keripik tempe "Selera Pemberani" ini juga merupakan tenaga kerja yang biasa disewa pula oleh pengusaha keripik yang lain, karena pengusaha keripik tempe "Selera
Pemberani" ini tidak memiliki tenaga kerja harian akan tetapi panggilan. Oleh karenanya makna eksistensi industri/pengusaha kecil telah dirasakan oleh warga sekitar tempat usaha karena mampu memberi peluang kerja untuk tetangga sekitar tempat usaha tersebut.

\section{Kondisi Manajemen dan Investasi}

Pada manajemen usaha Keripik Tempe "Selera Pemberani" dikelola dengan sederhana, dimana Ibu Ema sebagai pemilik usaha sekaligus berperan sebagai manajer. Kondisi manajemen belum baik, pembagian kerja sudah ada akan tetapi belum ada laporan keuangan secara tertulis dan terdokumentasi dengan baik. Akan tetapi sudah terbiasa mencatat aliran kas meski wujud laporan keuangan sederhana. Padahal dari laporan keuangan inilah dapat dijadikan dalam upaya pengelolaan keuangan yang baik sehingga bermanfaat bagi upaya merealisasikan pengembangan usaha. Selain itu mereka juga belum mampu membuat proyeksi keuangan untuk memastikan apakah pengembangan usaha akan menguntungkan atau sebaliknya. Bahan baku berupa tempe yang di beli dari daerah Malang Raya. Investasi meliputi : bangunan dari bambu sebagai tempat untuk proses pengirisan dan penggorengan dengan ukuran $3 \times 4$ meter serta rumah tinggal untuk proses pengemasan dan penjualan (display). Belum memiliki kendaraan sebagai sarana transportasi angkutan. Daerah pemasaran hanya beredar di sekitar area Malang Kota saja, karena menurut Ibu Ema semenjak suaminya meninggal dia tidak bisa pergi jauh dari rumah. Akan tetapi Ibu Ema telah mempunyai pelanggan lama yang masih pesan di usahanya berasal dari luar kota yakni Solo Jawa Tengah itupun menurutnya tidak pasti pesan tiap bulannya. Sebenarnya sudah ada beberapa penawaran pinjaman dana kredit usaha dengan bunga rendah dari 
beberapa Bank misalnya salah satunya BRI, tetapi mereka belum berani untuk mengambil kesempatan tersebut karena kurangnya modal yang mereka miliki. Hal ini dikarenakan kurang luasnya daya pemasaran sehingga pendapatan yang diterima oleh Ibu Ema hanya sebatas sekitar kota Malang saja dan kurangnya permintaan yang lebih luas dari luar kota Malang. Selain itu pemasaran yang sulit dikembangkan karena adanya persaingan dari munculnya usaha keripik tempe yang baru sehingga cenderung semakin menurun karena harga bahan baku kedelai yang tidak stabil dan tidak adanya informasi yang mendukung dari komunitas di antara para pengusaha keripik tempe dan menengah sehingga diharapkan dari mereka dapat menjembatani adanya permasalahan dari naiknya harga bahan baku kedelai atau permasalahan lainnya sehubungan dengan proses pembuatan keripik tempe yang kurang maksimal di antara beberapa pengusaha sehingga terkoordinir dari sesama pengusaha keripik tempe dan diharapkan tidak adanya kesenjangan pendapatan atau sampai mengalami gulung tikar diantara para usaha kripik tempe kecil dan menengah.

\section{Kondisi Produksi}

Produksi usaha keripik tempe
"Selera Pemberani" hanya mampu
menghasil kapasitas produksinya relatif
kecil yaitu $40-50$ bungkus keripik tempe per
gorengan, sehingga tiap minggunya Ibu Ema
ini bisa memproduksi keripik tempe hingga
100 bungkus dengan berat bersih per
bungkus kripik tempe adalah 100 gram atau
1 ons, oleh karena itu Ibu Ema hanya
mampu memenuhi permintaan pasar sebesar
$30 \%$, sehingga kebutuhan keripik tempe
yang mendesak tidak bisa terpenuhi,
kontinuitas produksi tidak tercapai, hasil
pengirisan yang manual tidak homogen dan
kualitas produksi rendah. Kapasitas

pengirisan cara manual hanya mencapai 500 irisan/jam $(3,25 \mathrm{~kg} / \mathrm{jam})$, dengan tebal irisan yang tidak seragam antara $1 \mathrm{~s} / \mathrm{d} 3,5 \mathrm{~mm}$ serta keamanan tangan tidak terjamin. Pengirisan yang dilakukan selama ini mempunyai banyak kelemahan, selain waktu proses yang lama kelemahan lainnya adalah tebal sayatan tidak bisa seragam, permukaan sayatan tidak rata (bergelombang) dan banyak membuang bahan baku tempe akibat tebal sayatan yang tidak seragam maka satu tempe kotak yang seharusnya menjadi 10 keping, rata-rata hanya menjadi 8 keping.

Proses pembuatan keripik tempe ini terbatas hanya sekitar 2 kali penggorengan saja tiap minggunya atau sekitar 80-100 bungkus. Waktu yang dibutuhkan dalam pembuatan keripik tempe ini sekitar 15 jam. Pada proses pengirisan tempe hanya menggunakan tenaga kerja satu orang saja, hal ini mengakibatkan proses selanjutnya juga berjalan dengan lambat. Sementara permintaan konsumen terkadang datang tiba-tiba akhirnya untuk pemesanan yang kurang dari 3 hari pasti tidak dapat terlaksana dengan baik, sehingga sering menolak untuk menerima order pemesanan keripik tempe kurang dari 3 hari. Untuk proses penggorengan secara bergantian, dan dilakukan di ruangan khusus yang dibuat oleh keluarga Ibu Ema sehingga tidak mengganggu aktivitas di dalam rumah utama. Pada proses pengemasan Ibu Ema menggunakan sealer atau alat pemanas yang digunakan untuk merekatkan plastik kemasan, sehingga proses pengemasan cukup higienis dan cepat. Bentuk kemasan yang mereka pakai ditempatkan di plastik biasa atau sederhana, serta tidak adanya label pada kemasan kripik tempe tersebut.

Beberapa kelemahan dalam teknik pengolahan keripik tempe ini adalah tidak adanya bahan pengawet alami yang dapat digunakan agar keripik tempe tersebut dapat memiliki masa layak konsumsi yang lebih 
panjang. Selain itu kurangnya tenaga kerja yang memadai serta sarana yang kurang mendukung juga mengakibatkan kapasitas produksi menjadi berkurang. Selain itu teknik pemasaran yang kurang efektif dan efisien dalam hal model kemasan yang kurang menarik pembeli agar terkesan higienis dan tahan lama. Ibu Ema juga belum merasakan peran yang siginifikan atas kehadiran komunitas pengusaha keripik tempe Sanan, kurangnya komunikasi dan sosialisasi program dari komunitas tersebut mengakibatkan pengusaha keripik tempe di wilayah Sanan kurang bekerja sama khususnya dalam hal mengembangkan dan mempertahankan usaha keripik tempe mereka masing-masing.

\section{METODE KEGIATAN}

Metode penyelesaian masalah yang akan dilaksanakan berdasarkan kesepakatan antara tim pelaksana IbM dengan kedua mitra UKM kripik tempe adalah sebagai berikut :

- Pendidikan Masyarakat

Memberikan penyuluhan tentang teknik komunikasi sehingga dapat membantu dalam memperluas produksi pemasarannya. Memberikan pelatihan tentang analisa BEP untuk UKM supaya para UKM dapat mengetahui untung dan ruginya dalam berwirausaha. Memberikan pelatihan tentang SOP operasional alat pengiris dan pengemas. Memberikan penyuluhan dan pendampingan tentang cara mendesain kemasan yang menarik. Pemberian modul tentang analisa BEP untuk usaha kecil menengah dan modul komunikasi pemasaran.

○ Difusi Ipteks
Memberikan bantuan alat berupa rancangan alat pengemas dan alat pengiris keripik tempe pada UKM Keripik tempe "Elang Jawa" dan UKM Keripik tempe "Selera Pemberan"

o Pelatihan

Melakukan kegiatan pelatihan atau demo tentang pemakaian alat. Mengadakan pelatihan tentang perawatan pada alat. Pemberian modul pelatihan alat pengiris tempe kepada kedua mitra.

\section{KARYA UTAMA}

Karya utama dalam kegiatan $\mathrm{IbM}$ ini adalah sebagai solusi dari permasalahan kedua mitra yaitu dengan memberikan bentuk teknologi tepat guna berupa alat pengiris tempe sebanyak 2 (dua) buah. Untuk dapat lebih meningkatkan kapasitas produksi alat pengirisan tempe bagi industri rumah tangga yang bergerak dalam produksi kripik tempe sesuai kemampuan mereka, maka perlu dilakukan rancang bangun mesin pengiris yang sesuai dengan kemampuan investasi dan biaya operasional industri rumah tangga tersebut (Rofarsyam, 2011). Spesifikasi alat pengiris tempe adalah sebagai berikut : ukuran $65 \times 55 \times 65 \mathrm{~cm}$, bahan stainless steel dan besi, kapasitas \pm 50 $\mathrm{kg} / \mathrm{jam}$, motor $1 / 4 \mathrm{HP}$, pisau berupa piringan, kecepatan $200 \mathrm{rpm}$ dan sebuah alat hand sealer dengan spesifikasi alat sebagai berikut : daya $500 \mathrm{~W}$, panjang $400 \mathrm{~mm}$, lebar $3 \mathrm{~mm}$, waktu pemanasan $0,2 \mathrm{~s} / \mathrm{d} 1,5$ (s), ketebalan 0,5 mm. Berdasarkan data hasil pengabdian masyarakat ini, maka perlu adanya teknologi untuk membantu peningkatan potensi UKM kripik tempe kedua mitra. Data hasil analisa serta hasil perubahan setelah kegiatan IbM tersebut adalah sebagai berikut : 
Tabel 1. Hasil perkembangan antara sebelum dan sesudah IbM.

\begin{tabular}{|c|l|c|c|c|c|}
\hline \multirow{2}{*}{$\begin{array}{c}\text { N } \\
\mathbf{0}\end{array}$} & \multirow{2}{*}{ Komponen } & \multicolumn{2}{|c|}{ Elang Jawa } & \multicolumn{2}{c|}{ Selera Pemberani } \\
\cline { 2 - 6 } & Sebelum IbM & Sesudah IbM & Sebelum IbM & Sesudah IbM \\
\hline 1 & Beban Pekerjaan & Lebih berat & Lebih ringan & Lebih berat & Lebih ringan \\
\hline 2 & Waktu Proses & $\begin{array}{c}\text { Tidak efektif } \\
(3 \mathrm{jam})\end{array}$ & $\begin{array}{c}\text { Efektif } \\
(1,5-2 \mathrm{jam})\end{array}$ & $\begin{array}{c}\text { Tidak efektif } \\
(4 \mathrm{jam})\end{array}$ & $\begin{array}{c}\text { Efektif } \\
(1,5-2 \mathrm{jam})\end{array}$ \\
\hline 3 & $\begin{array}{l}\text { Kapasitas } \\
\text { Produksi }\end{array}$ & $250 \mathrm{bgks} / \mathrm{bln}$ & $300 \mathrm{bgks} / \mathrm{bln}$ & $150 \mathrm{bgks} / \mathrm{bln}$ & $200 \mathrm{bgks/bln}$ \\
\hline 4 & $\begin{array}{l}\text { Omzet } \\
\text { Penghasilan }\end{array}$ & Rp 6.125.000,- & Rp 6.735.000 & $\begin{array}{c}\text { Rp } \\
3.675 .000,-\end{array}$ & Rp 4.060.000,- \\
\hline
\end{tabular}

\section{ULASAN KARYA}

Keunggulan dari teknologi alat pengiris tempe ini adalah sebagai alat untuk mengiris tempe yang bermanfaat sebagai alat bantu para UKM dalam proses pengirisan tempe sehingga waktu pemrosesan akan lebih cepat efektif dan efisien.Hasil yang didapat pun akan lebih banyak dan lebih cepat dihasilkan sehingga dapat memenuhi pemesanan lebih banyak dan memenuhi permintaan konsumen lebih banyak dari biasanya. Alat pengemas yaitu hand sealer lebih banyak membantu dapat pengemasan sehingga hasil yang diperoleh lebih higienis karena lebih rapat dalam menutup kemasan serta dibantu dengan ketebalan plastik yang membantu waktu penyimpanan lebih lama atau masih renyah (tidak mudah "melempem"). Hal ini akan membantu memperluas daerah pemasaran. Selain itu dengan pemberian mesin pengiris tempe akan meningkatkan produksi kripik tempe sehingga dapat memenuhi permintaan pasar. Memberikan metode cara menganalisa BEP dalam menjalankan usahanya sangat banyak membantu dalam hal penjualan produk sehingga kedua mitra mengetahui titik impas dimana usaha mereka tidak mengalami untung atau pun rugi, sehingga mereka mengetahui batas mulai mengetahui banyaknya keuntungan yang diperoleh dalam bentuk rupiah maupun unit. Selain itu dengan pemberian pelatihan cara komunikasi pemasaran yang baik akan membantu mendorongnya proses pemasaran yang semakin luas dengan menggunakan teknik komunikasi pemasaran sehingga pelanggan atau konsumen akan lebih tertarik untuk membeli dengan cara mereka memberikan promosi produknya. Dengan memberikan bahasa dagang merupakan trik untuk menarik minat konsumen supaya ingin membeli lebih banyak dan ditambah lagi dengan cara bentuk kemasan yang menarik sehingga peminat para konsumen semakin besar untuk lebih banyak memesan dari biasanya. Beberapa teknologi yang telah diberikan berupa alat dan pendidikan pelatihan, memberikan tambahan pendapatan ekonomi mereka dalam menjalankan usaha, dimana yang kita tahu bahwa persaingannya dalam usaha kripik tempe sangatlah ketat.

Karya yang telah dihasilkan dari kegiatan IbM ini telah sesuai dengan perkembangan dan kebutuhan masyarakat UKM kripik tempe dan memiliki nilai penting untuk perkembangan usaha kripik tempe dari kedua mitra "Elang Jawa" dan "Selera Pemnerani" dengan adanya peningkatan omzet dari kedua UKM kripik tempe serta peningkatan kapasitas produksi.

\section{DAMPAK DAN MANFAAT KEGIATAN}




\section{Dampak}

Pada kegiatan program IbM ini dampaknya adalah kedua mitra UKM kripik tempe adalah pada beban pekerjaan dirasa semakin ringan karena terbantukan adanya alat pengiris tempe. Waktu proses yang mereka gunakan juga lebih efektif dari 3 jam menjadi sekitar 1-1,5 jam. Kapasitas produksi yang semakin meningkat dari 105 bgks/bln menjdi 210 s/d 315 bgks/bln. Omzet penghasilan yang mereka peroleh semakin meningkat dan Rp 4.000.000 /bln menjadi Rp 8.000.000 s/d 12.000. 000. Selain itu meningkatnya pemesanan kripik tempe dan memiliki waktu/lama penyimpanan semakin lama karena menggunakan hand sealer yang lebih rapat untuk menutup kemasan dan dengan menggunakan ketebalan plastik sekitar sekitar $0,5 \mathrm{~mm}$ sehingga daya kerapatannya lebih tinggi.

Pelatihan yang telah diperoleh untuk kedua mitra tersebut berdampak semakin menambah pengetahuan tentang bagaimana mengetahui bahwa usaha mereka akan mengalami keuntungan atau kerugian serta mengetahui besarnya target untuk mencari keuntungan yang akan mereka dapatkan berupa rupiah atau pun unit. Sehingga akan mengetahui berapa kapasitas yang akan mereka tambahkan sesuai dengan target penjualan. Jadi tidaka akan mengalami kerugian dalam melakukan usaha karena dapat menganalisa BEP yang akan menguntunkan mereka dalam memperoleh keuntungan atau laba usaha.

\section{Manfaat}

Adanya tambahan alat pengiris tempe yang baru maka dapat memenuhi permintaan pasar yang kadang-kadang mendesak dan permintaan yang banyak dari konsumen yang biasanya permintaan yang secara tiba-tiba ingin dipenuhi. Selain lama daya simpan yang dikarenakan bentuk kemasan yang benar akan memperluas jangkauan pemasaran dan disertai dengan lebih memahaminya trik dalam komunikasi pemasaran yang bermanfaat bagi para usaha kripik tempe untuk cara mempromosikan dagangan usahanya sehingga akan menambahkan jumlah pelanggan atau konsumen untuk memenuhi permintaan kripik tempe. Selain itu bentuk kemasan yang lebih menarik bagi konsumen untuk memesan produk usahanya. Manfaat lebih dirasakan adalah peningkatan omzet yang lebih besar 2 bahkan 3 kali lipat dari biasanya. Hal inilah yang paling mereka syukuri dengan adanya penambahan alat bantu dalam peningkatan usaha dengan dilengkapi dengan cara perawaratan dan penggunaan alat yang benar sehingga lebih awet dalam penggunaannya. Manfaat yang lain yaitu semakin menambah pengetahuan dan pemahaman dengan adanya teknologi baru berupa alat pengiris tempe dan hand sealer serta memahami bagaimana trik cara komunikasi pemasaran dari ilmu berwirausaha dan memahami cara menganalisis BEP dengan mudah dan cermat.

\section{KESIMPULAN}

1. Penghasilan semakin meningkat $10 \%$ dari kedua mitra

2. Kapasitas semakin bertambah $20 \%$ sehingga dapat memenuhi permin-taan pasar.

3. Beban pekerjaan semakin ringan sehingga tidak diperlukan tenaga kerja tambahan

4. Waktu proses lebih efektif 1,5-2 jam

5. Pengetahuan semakin bertambah dengan adanya alat pengiris tempe dan alat pengemas

6. Pengetahuan semakin bertambah dengan adanya aplikasi analisa BEP dalam mengetahui untung rugi usaha 
7. Pemahaman semakin meningkat dengan adanya teknik komunikasi pemasaran dalam usaha keripik tempe

\section{DAFTAR PUSTAKA}

1. Anonim, 2012, Cara Membuat Tempe. http://www.caramembuattempe.com (diakses 28 April 2014)

2. Anonim, 2013, Alat Penunjang wirausaha untuk UKM. http://kancra.weebly.com/ alat- penunjang-wirausaha-untuk-ukm-usahakecil-menengah.html (diakses 27 April 2014)

3. Anindia Rahayu, 2005. Proses pembuatan Natadekoko, Majalah Trubus, Edisi September, Vol. I No. 4, Jakarta

4. Rofarsyam, 2011. Rancang Bangun mesin Pengiris Tempe Sistem Pisau Berputar Horizontal, Semarang 